\title{
Praktek Nikah Paksa di Desa Cibeureum Kabupaten Ciamis
}

\author{
Anis Aljalis Rahmah \\ Institut Agama Islam Darussalam (IAID) Ciamis, Jawa Barat \\ Email: anis.aljalis12@gmail.com \\ Sumadi \\ Institut Agama Islam Darussalam (IAID) Ciamis, Jawa Barat \\ Rudi \\ Institut Agama Islam Darussalam (IAID) Ciamis, Jawa Barat
}

\begin{abstract}
ABSTRAK
Penelitian ini dilatar belakangi oleh rendahnya pengetahuan tentang pentingnya melibatkan anak untuk pemilihan pasangan untuk dirinya sendiri dan menentukan kesiapan dirinya untuk menikah baik itu kesiapan mental maupun materi. Dan untuk memberitahukan kepada masyarakat bahwa pernikahan atas dasar pemaksaan termasuk kedalam kekerasan dalam rumah tangga.Metode penelitian yang digunakan adalah metode penelitian lapangan (fieled research), yang mana penelitian ini menitik beratkan pada hasil pengumpulan data dari informan yang telah ditentukan. Sedangkan teknik pengumpulan data yang digunakan adalah wawancara, observasi dan dokumentasi. Setelah melakukan penelitian, hasil yang diperoleh adalah orang tua-orang tua yang menikahkan anak-anaknya secara paksa itu bertujuan untuk mengurangi beban mereka secara materi mapun secara tanggung jawab. Karena anak yang sudah menikah mereka anggap bukan lagi tanggung jawab mereka.
\end{abstract}

\section{ABSTRACT}

This research is motivated by the low knowledge about the importance of involving children in choosing a partner for themselves and determining their readiness for marriage, both mental and material readiness. And to inform the public that marriage on the basis of coercion is included in domestic violence. The research method used is the field research method, in which this research focuses on the results of data collection from predetermined informants. While the data collection techniques used were interviews, observation and documentation. After conducting the research, the results obtained were parents who forcibly married their children to reduce their burden materially and responsibly. Because children who are already married they consider it no longer their responsibility. 
Keywords: Forced marriage, law on the elimination, domestic violence

\section{PENDAHULUAN}

Allah menciptakan semua makhluk berpasang-pasangan, tak terkecuali manusia yang pada dasarnya mempunyai sifat zoon politicon, yaitu selalu mencari manusia lainnya untuk bersama, oleh karena itu manusia akan selalu berusaha untuk mewujudkan suatu jalinan kehidupan bersama dalam masyarakat, keinginan untuk selalu berkumpul dan berkomunikasi merupakan hukum agama yang tersirat, yang diatur dalam suatu ikatan perjanjian yang suci dan kokoh untuk membentuk suatu keluarga bahagia dan kekal, masyarakat lebih mengenal perjanjian tersebut dengan istilah nikah (Abbas, 2006:4).

Pernikahan dalam Islam diatur sedemikian rupa, oleh karena itu nikah sering disebut sebagai perjanjian suci untuk membentuk keluarga yang bahagia. Salah satu tujuan syari'at Islam (maqasid asy-syari'ah) sekaligus tujuan nikah adalah hifz an-nasab yakni terpeliharanya kesucian ke terunan manusia sebagai pemegang amanah khalifah fil al-ard. Tujuan syari'at ini dapat dicapai melalui jalan pernikahan yang sah menurut agama, diakui oleh undang-undang dan diterima sebagai bagian dari budaya masyarakat (Rofiq, 1997:220).

Pernikahan merupakan hak dan kebutuhan setiap manusia sebagaimana yang disebutkan oleh Lopa (1996:65) bahwa setiap manusia memiliki hak untuk meneruskan keturunan dengan jalan menikah dan berkeluarga sebagai hak asasi manusia pemberian Tuhan. Meskipun demikian aturan pernikahan tersebut harus dijamin oleh lembaga yang berwenang agar pelaksanaannya berjalan tertib, sehingga tidak merugikan hak asasi manusia. Oleh karena itu wajar apabila sebelum memutuskan untuk masuk ke jenjang pernikahan laki-laki atau perempuan selayaknya menggunakan banyak pertimbangan dalam memilih pasangan hidupnya.

Pernikahan bisa menjadi jembatan kebahagian setiap pelakunya, bila pernikahan dilandasi dengan sukarela, kasih sayang, saling melindungi. Tapi juga bisa menjadi jembatan kehancuran apabila pernikahan dilakukan dengan keterpaksaan belaka. Nikah merupakan keistimewan dan masalah pribadi setiap orang, sehingga harus berdasarkan kemauan antar kedua belah pihak dan tidak ada pamaksaan dari pihak manapun agar menjadikan keluarga yang sakinah, mawadah, warahmah kedepannya.

Seorang ayah yang menikahkan putrinya tanpa kerelaannya, seolaholah ayahnya lah yang akan menikah, bukan anak perempuannya. Dia tidak mengikut sertakan pendapat putrinya, menghapus keputusannya, dan mengharuskannya untuk menikah dengan pria yang tidak dicintai dan tidak disenanginya (Ghamidi, 2008:267). Pemaksaan orang tua atau salah satu orang tua terhadap anaknya untuk menikah dengan seseorang yang tidak 
diinginkan oleh sang anak adalah termasuk kepada kekerasan dalam rumah tangga secara psikologis.

Pelanggaran terhadap hak wanita dalam memilih suami dan teman hidupnya yang selama ini sering kita dengar merupakan sebuah kezhaliman, merenggut haknya, merampas keputusannya yang istimewa, dan tidak mengikutsertakannya dalam menentukan pilihan terpenting dalam hidupnya (Ghamidi, 2008:269). Pelaku kekerasan dalam rumah tangga bukan hanya seorang suami terhadap istrinya tetapi juga bisa dilakukan terhadap orangtua kepada anak. Juga kekerasan dalam rumah tangga bukan hanya soal fisik melainkan juga psikologis.

Undang-undang No 23 Tahun 2004 tentang Penghapusan Kekerasan dalam Rumah Tangga pasal 1 ayat (1) menjelaskan bahwa kekerasan dalam rumah tangga ada 4 yaitu: fisik, seksual, psikologis, dan atau penelantaran rumah tangga termasuk ancaman untuk melakukan perbuatan, pemaksaan, atau perampasan kemerdekaan secara melawan hukum dalam lingkup rumah tangga, di undang-undang tersebut juga disebutkan bahwa pelaku kekerasan dalam rumah tangga itu bisa suami, istri, anak dan bahkan pembantu rumah tangga. Dengan demikian, masalah pokok dalam penelitian ini, yaitu: Bagaimanakah praktek nikah paksa di Desa Cibeureum Kabupaten Ciamis menurut Undang-undang No.23 Tahun 2004 tentang Penghapusan Kekerasan dalam Rumah Tangga ?

\section{KONSEP PERNIKAHANPAKSA}

Nikah adalah salah satu bahasa Arab yang telah baku menjadi kata Indonesia, makna asalnya ialah: berkumpul, menindas dan memsukan (sesuatu) disamping juga berarti bersetubuh dan berakad. Adapun yang dimaksud dengan nikah menurut istilah para ahli Islam (fuqaha) seperti dikemukakan oleh sebagian zmereka ialah "sesuatu akad yang dengannya hubungan kelamin antara pria dengan wanita yang melakukan akad (perjanjian) tersebut menjadi halal" (Hidayattullah, 2002:856).

Menurut bahasa, nikah berarti penyatuan. Diartikan juga sebagai akad atau hubungan badan. Selain itu, ada juga yang mengartikannya dengan percampuran. al-fara' mengatakan: "an-Nukh" adalah sebutan untuk kemaluan. Disebut sebagai akad, karena ia merupakan penyebab terjadinya kesepakatan itu sendiri. Sedangkan al-Azhari mengatakan: Akar kata nikah dalam ungkapan bahasa Arab berarti hubungan badan. Sementara itu alFarisi mengatakan: "jika mereka mengatakan, bahwa si fulan atau anaknya fulan menikah, maka yang dimaksud adalah mengadakan akad. Akan tetapi, jika dikatakan, bahwa ia menikahi istrinya, maka yang dimaksud adalah hubungan badan" (Muhammad, 2007:375).

Adapun menurut syari'at, nikah juga berarti akad. Sedangkan pengertian hubungan badan itu hanya merupakan metafora saja. Hujjah (argumentasi) atas pendapat ini adalah banyaknya pengertian nikah yang 
terdapat di dalam al-qur'an maupun hadis sebagai akad. Bahkan dikatakan, bahwa nikah itu tidak disebutkan didalam al-qur'an melainkan diartikan dengan akad. Sebagaimana firman-Nya: "Sehingga ia menikah dengan lakilaki lain" yang tidak dimaksudkan sebagai hubungan badan. Karena, syarat hubungan badan yang membolehkan rujuknya seorang suami yang telah menceraikan istrinya hanya diterangkan di dalam sunnah Rasulullah saw. Dengan demikian, maka firman Allah diatas adalah, sehingga menjalin pertalian atau akad. Pemahaman lain, bahwa dengan akad tersebut, maka menjadi boleh pada apa yang dilarang (Muhammad, 2007:375).

Istilah nikah Paksa secara tekstual memang tidak disebutkan dalam literatur-literatur kitab fiqh, bahkan dalam al-Qur'an dan hadispun tidak disebutkan secara Implisit, namun dalam perwalian, salah satu disebutkan tentang ijbar dan wali mujbir. Pemahaman istilah tersebut yang kemudian muncul tentang pemahaman nikah paksa, dimana hak ijbar ini dipahami sebagai hak memaksakan suatu pernikahan oleh orang lain dalam hal ini adalah ayahnya.

Adapun pengertian ijbar sendiri adalah suatu tindakan untuk melakukan sesuatu atas dasar tanggung jawab (Muhammad, 2001:79). Di dalam fiqh Islam istilah ijbar sendiri erat kaitannya dengan persoalan pernikahan. Dalam Fiqh Syafi'i disebutkan bahwa yang memiliki kekuasaan atau hak ijbar adalah ayah atau kakeknya, jadi apabila seorang ayah dikatakan sebagai wali mujbir, maka dia adalah orang yang memiliki kekuasaan atau hak untuk mengawinkan anak perempuannya, meskipun tanpa persetujuan dari orang yang bersangkutan dan pernikahan tersebut dipandang sah secara hukum.(Muhammad, 2001:80)

Memahami hak ijbar diatas, dapat diambil kesimpulan bahwa kekuasaan seorang ayah terhadap gadisnya untuk menikah dengan seorang laki-laki, bukanlah sesuatu tindakan memaksakan kehendaknya sendiri dengan tidak memerhatikan kerelaan sang gadis, melainkan sebatas mengawinkan, dengan asumsi dasar anak perempuannya belum atau tidak memiliki kemampuan untuk bertindak sendiri (Muhammad, 2007:80).

Ada beberapa tujuan dari disyariatkannya pernikahan atas umat Islam menurut Syarifuddin ( 2014:46-47 ) diantaranya adalah: Pertama, untuk mendapatkan anak keturunan yang sah bagi melanjutkan generasi yang akan datang. Hal ini terlihat dari isyarat firman Allah sebagai berikut "Wahai manusia bertakwalah kepada Tuhanmu yang telah menciptakan kamu dari diri yang satu (Adam), dan (Allah) menciptakan pasangannya (Hawa) dari (diri)nya; dan dari keduanya Allah memperkembangbiakan laki-laki dan perempuan yang banyak. Bertakwalah kepada Allah yang dengan nama-Nya kamu saling meminta dan (peliharalah) hubungan kekeluargaan. Sesungguhnya Allah selalu menjaga dan mengawasimu (Q.S an-Nisa:1).

Keinginan untuk melanjutkan keturunan merupakan naluri atau garizah umat manusia bahkan juga garizah bagi makhluk hidup yang diciptakan Allah. Untuk maksud itu Allah menciptakan bagi manusia nafsu 
syahwat yang dapat mendorongnya untuk mencari pasangan hidupnya untuk menyalurkan nafsu syahwat tersebut. Untuk memberi saluran yang sah dan legal bagi penyaluran nafsu syahwat tersebut adalah melalui lembaga pernikahan.

Kedua, untuk mendapatkan keluarga bahagia yang penuh dengan ketenangan hidup dengan rasa kasih sayang. Hal ini terlihat dari firman Allah dalam surat ar-Rum ayat 21 sebagai berikut: "Dan diantara tandatanda kekuasaan-Nya ialah Dia menciptakan untukmu istri-istri dari jenismu sendiri, supaya kamu cenderung dan merasa tentram kepadanya, dan dijadikan-Nya diantaramu rasa kasih dan sayang. Sesungguhnya pada demikian itu benar-benar terdapat tanda-tanda bagi kaum yang berfikir (Q.S Ar-rum:21).

Penyaluran nafsu syahwat untuk menjamin kelangsungan hidup umat manusia dapat saja ditempuh melalui jalur luar pernikahan, namun dalam mendapatkan ketenangan dalam hidup bersama suami istri itu tidak mungkin didapatkan kecuali melalui jalur pernikahan.

Menurut undang-undang No.1 merumuskan bahwa "perkawinan ialah ikatan lahir batin antara seorang pria dan wanita sebagai suami istri dengan tujuan membentuk keluarga (rumah tangga) yang bahagia dan kekal berdasarkan Ketuhanan yang Maha Esa".

Berdasarkan uraian di atas menurut Rauf (1996:40) pernikahan dapat dijabarkan sebagai berikut: (1) melaksanakan ikatan perkawinan antara pria dan wanita yang sudah dewasa guna membentuk kehidupan rumah tangga; (2) mengatur kehidupan seksual antara seorang laki-laki dan perempuan sesuai dengan ajaran dan firman Tuhan yang Maha Esa; (3) memperoleh keturunan untuk melanjutkan kehidupan kemanusiaan dan selanjutnya memelihara pembinaan terhadap anak-anak untuk masa depan; (4) memberikan ketetapan tentang hak dan kewajiban suami isteri dalam membina kehidupan keluarga; dan (5) mewujudkan kehidupan masyarakat yang teratur, tentram dan damai.

Sedangkan menurut Imam al Ghozali yang dikutip oleh Abdul Rohman Ghozali (2003:22) tujuan perkawinan adalah:

a) Mendapatkan dan melangsungkan keturunan

b) Memenuhi hajat manusia untuk menyalurkan syahwat dan menumpahkan kasih sayang

c) Memenuhi panggilan agama, memelihara diri dari kejahatan dan kerusakan

d) Menumbuhkan kesungguhan untuk bertanggung jawab menerima hak serta kewajiban dan untuk memperoleh harta kekayaan yang halal

e) Membangun rumah tangga untuk membentuk masyarakat yang tentram atas dasar cinta dan kasih sayang.

Islam sangat menganjurkan umatnya untuk menikah karena beberapa sebab. Manfaat dari nikah itu sendiri dapat dirasakan oleh 
individu yang bersangkutan secara pribadi, masyarakat secara umum, serta komunitas manusia secara menyeluruh.

Menurut Sabiq (2016:446-448) hikmah-hikmah dalam nikah adalah sebagai berikut

1) Nafsu seks adalah nafsu yang sangat kuat dan sulit dibendung. Naluri seksual mengarahkan manusia untuk berusaha mencari sarana untuk menyalurkannya. Apabila tidak terpenuhi, seseorang akan dihinggapi perasaan gelisah dan bahkan terjerumus pada hal-hal yang kurang baik.

Sarana terbaik untuk menyalurkan naluri seksual manusia adalah nikah. Nikah menjauhkan manusia dari rasa gundah dan gelisah, menjaga pandangan dari sesuatu yang diharamkan, dan mengarahkan hati kepada yang telah dihalalkan oleh Allah. Allah berfirma, “Dan diantara tanda-tanda kekuasaan-Nya ialah Dia menciptakan untukmu istri-istri dari jenismu sendiri, supaya kamu cenderung dan merasa tentram kepadanya, dan dijadikan-Nya diantaramu rasa kasih dan sayang. Sesungguhnya pada demikian itu benar-benar terdapat tanda-tanda bagi kaum yang berfikir (Q.S Ar-rum:21)

Abu Hurairah berkata bahwa Rasulullah saw bersabda:

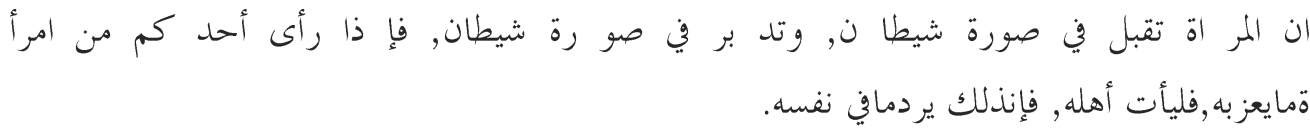

Perempuan itu (dilihat) dari depan ibarat setan (menggoda), dari belakang juga begitu. Apabilah seorang laki-laki tergoda oleh seorang perempuan, hendaklah ia mendatangi (menyalurkan hasratnya kepada) istrinya agar terhindar dari apa yang menimpa dirinya (godaan setan).

2) Sarana terbaik untuk menjada agar garis keturunan tidak terputus dan memperbanyak keturunan adalah dengan melalui pernikahan. Islam sangat menekankan pentingnya nasab dan melindunginya. Rasulullah saw bersabda:

$$
\text { تزوجو الولود فإني مكاثر بكم الأنبياءيو مالقيامة }
$$

Nikahlah dengan perempuan yang lemah lembut dan dapat memberikan keturunan yang banyak; karena aku akan membanggakan diri kalian pada Para Nabi pada hari kiamat dengan banyaknya jumlah kalian".

Banyak manfaat yang dapat diperoleh dari keturunan yang banyak, sehingga setiap negara sangat memperhatikan dan berusaha untuk memperbanyak penduduknya dengan memberikan penghargaan kepada siapapun yang memiliki keturunan yang banyak. Orang terdahulu selalu berkata, "Sesungguhnya kemuliaan itu diperuntukan bagi yang banyak kerabatnya". Slogan ini masih berlaku hingga saat ini dan belum ada yang bertolak belakang dengannya. Saat Ahnaf bin Qais datang kepada Mu'awiyah, Mu'awiyah sedang bersama putranya yang bernama Yazid. Lalu Mu'awiyah bertanya kepadanya, "Wahai Abu Bahr, apa pendapatmu tentang anak ?". Ahnaf menjawab, “Wahai Amirul Mu'minin, anak-anak adalah penopang, buah hati serta cahaya mata kita. Dengan adanya mereka, 
kita mengalahkan musuh-musuh kita. Anak-anak adalah generasi penerus kita. Karena itu, bagaimanapun keadaanya, berilah jika mereka meminta sesuatu darimu, ridhailah jika mereka mengharapkan ridha darimu, jangan halangi mereka dari pemberiamu sehingga mereka memusuhi dan membencimu serta mengharapkan kematianmu." Kemudian Mu'awiyah berkata, "Demi Allah. Benar sekali ucapanmu. Memang seperti itulah adanya mereka.

3) Naluri kebapaan dan keibuan dapat tersalurkan melalui nikah. Naluri itu berkembang secara bertahap sejak masa kanak-kanak, begitu pula perasaan kasih sayang dan kelembutan. Tanpa itu semua, seorang manusia tidak akan merasa sempurna.

4) Tanggung jawab nikah dan keinginan untuk mengayomi keluarga dapat menjadikan seseorang bersemangat dan berusaha keras dalam mengembangkan kreativitasnya. Ia akan bekerja untuk memenuhi kewajiban dan kebutuhan rumah tangganya, hingga akhirnya ia menjadi pekerja keras yang dapat menghasilkan kekayaan dan produktif dalam menggali khazanah yang telah disediakan Allah untuk makhluknya.

5) Ada pembagian tugas yang jelas antara suami dan istri, baik didalam maupun diluar rumah berikut kewajiban yang harus dipenuhi sesuai kemampuan;

Perempuan berkewajiban untuk mengurus kebutuhan rumah tangga, mengurus anak, dan menciptakan suasana yang kondusif yang dapat menghilangkan penat suami setelah bekerja dan mengembalikan semangatnya untuk selalu berusaha dan bekerja dalam memenuhi kebutuhan rumah tangga.

Apabila suami istri dapat menjalankan kewajiban mereka dengan sebaik-baiknya, maka akan tercipta rumah tangga yang diridhai Allah dan dapat menghasilkan generasi-generasi pilihan.

6) Menyatukan keluarga kedua pasangan, menumbuhkan jalinan kasih sayang sesama mereka, serta memperkuat ikatan sosial didalam masyarakat. Ikatan sosial inilah yang sangat dianjurkan dan didukung oleh syariat Islam. Pada dasarnya, masyarakat yang solid dan saling berkasih sayang adalah masyarakat yang kuat dan berbahagia.

7) Memperpanjang usia. Hal ini merupakan SK PBB yang disebarluaskan oleh majalah asy-Sya'b yang diterbitkan pada tanggal 6 juni 1959 disebutkan bahwa orang yang menikah dapat hidup lebih lama daripada orang yang tidak menikah; baik itu duda-janda maupun orang yang hidup membujang.

Pernikahan adalah suatu akad yang suci dan luhur antara laki-laki dan perempuan sebagai suami istri dan dihalalkannya hubungan seksual dengan tujuan mencapai keluarga yang sakinah, mawadah, warahmah, penuh kebijakan dan saling menyantuni. Nikah adalah sunnatullah pada hamba-hambanya. Dengan menikah, Allah menghendaki agar mereka 
mengemudikan bahtera kehidupan secara bersama. Di dalam Al-Qur'an disebutkan tentang perintah untuk menikah.

Menikah hukumnya wajib bagi yang sudah mampu, nafsunya sudah sangat bergejolak, dan takut terjerumus dalam perzinaan, maka ia wajib menikah. Karena, menghindarkan diri dari yang haram ialah wajib. Dan hal itu tidak dapat dilakukan dengan baik kecuali dengan jalan nikah.

Qurthubi berkata, "seorang lajang yang sudah mampu menikah dan khawatir diri dan agamanya menjadi rusak, sedangkan tidak ada jalan lain untuk menyelamatkan dirinya kecuali denga menikah,maka tidak ada perselisihan pendapat tentang wajibnya ia menikah. Jika nafsunya telah memuncak, sedangkan ia tidak mampu membelanjai istrinya, maka Allah akan melapangka rezekinya (Sabiq, 2006:491).

1) Al-Qur'an

a) Q.S An-Nur:21, “Dan diantara tanda-tanda kekuasaan-Nya ialah Dia menciptakan untukmu istri-istri dari jenismu sendiri, supaya kamu cenderung dan merasa tentram kepadanya, dan dijadikan-Nya diantaramu rasa kasih dan sayang. Sesungguhnya pada demikian itu benar-benar terdapat tanda-tanda bagi kaum yang berfikir (Q.S Ar-rum:21).

b) Q.S An-Nur:32, "Dan nikahlah orang-orang yang sendirian diantara kamu, dan orang-orang yang layak (bernikah) dari hamba-hamba sahayamu yang lelaki dan hamba-hamba sahayamu yang perempuan. Jika mereka miskin Allah akan memampukan mereka dengan karunia-Nya. Dan Allah maha luas (pemberian-Nya) lagi maha mengetahui (Q.S An-Nur:32).

2) Hadis

a) Hadis yang diriwayat-kan oleh al-Bukhari dari 'Abdullah bin Mas'ud Radhiyallahu anhu.

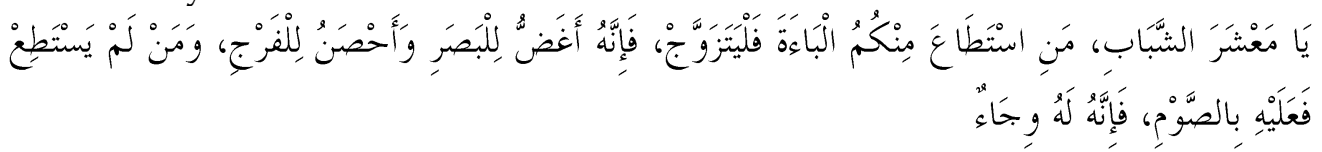

Wahai para pemuda, barangsiapa di antara kalian yang mampu menikah, maka menikahlah. Karena menikah lebih dapat menahan pandangan dan lebih memelihara kemaluan. Dan barangsiapa yang tidak mampu, maka hendaklah ia berpuasa; karena puasa dapat menekan syahwatnya (sebagai tameng) (H.R Bukhari no.5066).

Hukum pernikahan dalam Islam dapat digolongkan menjadi lima macam, yaitu:

(1) Wajib, pernikahan wajib hukumnya bagi orang yang telah berkeinginan kuat untuk menikah, telah mempunyai kemampuan untuk melakukan dan bertanggungjawab akan kewajibannya dan khawatir apabila tidak menikah akan mudah terjerumus dalam perbuatan zina. 
(2) Sunnah, pernikahan hukumnya sunnah bagi orang yang telah berkeinginan kuat untuk menikah, mempunyai kemampuan untuk melakukan dan bertanggung jawab akan kewajibannya, tetapi tidak khawatir melakukan perbuatan zina bila tidak menikah.

(3) Haram, pernikahan haram hukumnya bagi orang yang belum berkeinginan serta tidak mempunyai kemampuan untuk melaksanakan dan bertanggung jawab atas kewajibannya, karena justru bila kawin akan membawa kemudharatan.

(4) Makruh, pernikahan menjadi makruh hukumnya bagi orang yang telah berkeinginan kuat untuk menikah, tetapi dikhawatirkan tidak atau belum mempunyai kemampuan untuk melaksanakan dan bertanggung jawab akan kewajibannya dan apabila tidak menikah tidak ada kekhawatiran akan berbuat zina.

(5) Mubah, pernikahan menjadi mubah hukumnya bagi orang yang tidak terdesak oleh alasan-alasan yang mewajibkan menikah maupun alasan-alasan yang mengharamkan nikah (Ghazaly, 2003:8).

Syarat yang dimaksud dalam pernikahan ialah suatu hal yang pasti ada dalam pernikahan. Akan tetapi tidak termasuk salah satu bagian dari hakikat pernikahan. Dengan demikian rukun nikah itu wajib terpenuhi ketika diadakan akad nikah, sebab tidak sah akadanya jika tidak terpenuhi rukunya (As-Syaukani, 2006:404).

Jadi rukun dan syarat itu saling berkaitan satu sama lain dan saling melengkapi, jadi jika seseorang akan melaksanakan nikah harus memenuhi rukun dan syarat dalam pernikaha tersebut.

Sementara itu sahnya pernikahan sebagaimana disebut dalam undang-undang Pernikahan pasal 2 ayat (1) dikatakan bahwa nikah adalah sah, apabila dilakukan menurut agamanya dan kepercayaannya itu. Maka bagi umat Islam ketentuan mengenai terlaksananya akad nikah dengan baik tetap mempunyai kedudukan yang sangat menentukan mengenai sah sebuah pernikahan adalah sebagai berikut.

1) Adanya calon mempelai pria maupun calon mempelai wanita.

Menurut Thalib (1974:66) menjelaskan bahwa antara keduamya harus ada persetujuan bebas, yaitu persetujuan yang dilahirkan dalam keadaan pikiran yang sehat dan bukan karena paksaan. Disyaratkan persetujuan bebas adalah pertimbangan yang logis karena dengan tidak adanya persetujuan bebas ini berarti suatu indikasi bahwa salah satu pihak atau keduanya tidak memiliki hasrat untuk membentuk kehidupan keluarga sebagai salah satu yang menjadi tujuan pernikahan.

2) Kewajiban membayar mahar

Mahar adalah sesuatu yang diberikan calon suami kepada calon istri untuk mengahalkan menikmatinya (al-Jaza'iri, 2009:750).

Mahar atau maskawin dalam hukum Islam adalah sesuatu yang wajib di bayar oleh calon mempelai laki-laki kepada calon mempelai wanita. Hal ini sesuai dengan firman Allah dalam surat An-Nisa ayat 4:"Berikanlah 
maskawin (mahar) kepada perempuan (yang kamu nikahi) sebagai pemberian yang penuh kerelaan. Kemudian, jika mereka menyerahkan kepada kamu sebagian dari (maskawin) itu dengan senang hati, maka terimalah dan nikmatilah pemberian itu dengan senang hati (Q.S AnNisa:4).

Adapun ukuran besarnya maskawin itu tidak dibatasi oleh syariat Islam, hanya menurut kekuatan suami beserta keridhaan si istri. Sungguhpun demikian hendaklah dengan benar-benar suami sanggup membayarnya karena mahar itu apabila telah ditetapkan sebanyak ketetepan itu menjadi utang atas suami wajib dibayar semana utang kepada orang lain, kalau tidak dibayar akan menjadi soal dan pertanggung jawaban di hari kemudian. Janganlah terperdaya dengan adat bermegah-megah dengan banyak mahar sehingga si laki-laki menerima perjanjian itu karena utang, katanya, sedangkan ia tidak ingat akibat yang akan menimpa dirinya sendiri juga terhadap perempuan (istri) dia wajib membayar zakat maharnya itu sebagaimana dia wajib membayar zakat uangnya yang dipiutangnya. (Rasyid, 1992:365).

3) Harus dihadiri wali dari calon mempelai wanita

Adanya wali bagi seorang wanita didalam pelaksanaan akad nikahnya merupakan rukun dari akad nikahmya tersebut. Adapun syaratsyarat untuk menjadi wali nikah secara teknis yaitu,laki-laki, muslim akil dan baligh (Rofiq,1995:71). Seperti yang dijelaskan dalam

Hadis Nabi saw.

$$
\text { لانكا ح إللآ بولي }
$$

Tidak (sah) sebuah pernikahan kecuali dengan (seizin) wali. Hadis riwayat Aisyah RA, bahwa Nabi Muhammad SAW bersabda: Rukun nikah ada tiga, yaitu:

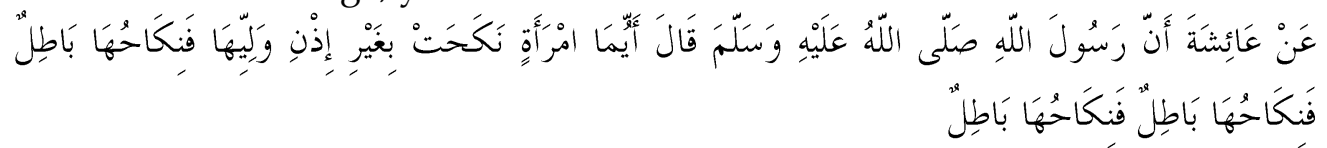

Dari Aisyah bahwa Rasulullah saw shallallahu 'alaihi wasallam bersabda: "Wanita manapun yang menikah tanpa seizin walinya maka nikahnya adalah batal, nikahnya adalah batal, nikahnya adalah batal

Dua hadis di atas memperjelas bahwa adanya wali merupakan syarat sahnya nikah, jika tidak ada wali maka nikahnya tidak sah atau batal.

Mayoritas ulama salaf maupun kalaf antara lain Ali, Umar, Ibnu Mas'ud, Abu Hurairah, Aisyah, Malik, Syafi'i Ahmad, Ishaq, Abu Ubaid, Ats-Tsauri, dan penganut Madzhab Zhahiri berpendapat bahwa wali adalah syarat keabsahan akad pernikahan. Sehingga jika seorang perempuan yang masih perawan menikahkan dirinya yang (tanpa wali) maka nikahnya adalah batal.

4) Harus disaksikan 2 orang saksi

Pernikahan hendaklah dihadiri dua orang saksi atau lebih dari kaum laki-laki yang adil dan beragama Islam (al-Jaza' iri, 2009:750). 
Syafi'i dan Hambali berpendapat bahwa pernikahan harus dengan dua orang laki-laki muslim dan adil. Sedangkan Maliki mengatakan saksi hukumnya tidak wajib dalam akad tetapi wajib untuk pencampuran suami dengan istrinya (dukhul). Kalau akad dilakukan tanpa seorang saksi pun, akad itu dipandang sah, tetapi apabila suami bermaksud mencampuri istri, dia harus mendatangkan dua orang saksi. Apabila ia mencampuri istrinya tanpa ada saksi, akadnya harus dibatalkan secara paksa, dan pembatalan akad nikah ini sama kedudukannya dengan talak ba'in (Mhughaniyah, 2010:314).

Syarat harusnya dihadirkan dua orang saksi dalam suatu pernikahan mengacu pada hadis nabi Muhammad saw, sebagai berikut:

Sabda Rasulullah saw:

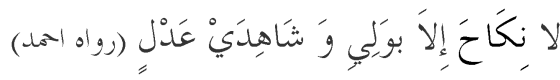

Tidak sah nikah kecuali dengan wali dan dua orang saksi yang adil (Riwayat Ahmad).

Adapun ketentuan hukum bagi kedua orang saksi menurut alJaza'iri (2009:750) adalah sebagai berikut:

a) Saksi nikah terdiri dari dua orang atau lebih.

b) Kedua orang saksi nikah hendaklah orang yang adil, yang dibuktikannya dosa-dosa besar dan kebanyakan dosa kecil. Sedangkan orang fasik adalah orang yanh biasa melakukan zina, meminum minuman keras, atau memakan harta riba, sehingga kesaksiannya dihukumi tidak sah. Hal tersebut berdasarkan Firman Allah:

Dan persaksikanlah dengan dua orang saksi yang adil diantara kalian (At-Thalaq:2).

Juga berdasarkan sabda Rasulullah saw:

$$
\text { لا نَكَاحَ إلاًَ بوَكَي وَ شَاهِدَيْ عَدْلِ (رواه احمد) }
$$

Tidak sah nikah kecuali dengan wali dan dua orang saksi yang adil. (Riwayat Ahmad)

c) Dimasa kita sekarang ini, sebaiknya jumlah saksi diperbanyak karena sedikitnya orang yang adil.

5) Ijab dan Qabul

Para ulama madzhab sepakat bahwa nikah baru dianggap sah jika dilakukan dengan akad, yang mencakup dengan ijab dan qabul antara wanita yang dilamar dengan lelaki yang melamarnya, atau antara pihak yang digantikannya seperti wakil dan wali, dan dianggap tidak sah hanya berdasarkan suka sama suka tanpa adanya akad (Mhughaniyah, 2010:309).

Para ulama juga sepakat bahwa nikah itu sah bila dilakukan dengan menggunakan redaksi زوجت (aku mengawinkan) atau انكحت (aku menikahkan) dari pihak yang dilamar atau orang yang mewakilinya dan redaksi qabiltu (aku terima) atau raditu (aku setuju) dari pihak yang melamar atau orang yang mewakilinya (Mhughaniyah, 2010:309). 
Kemudian dari kelima rukun nikah tersebut, terdapat syarat yang menjadikan syahnya suatu perkawinan. Jadi jika syarat-syarat terpenuhi, maka pernikahan menjadi sah dan dari sanalah menjadi timbul skala kewajiban dan hak-hak nikah (Sabiq, 1992:48).

Wali nikah adalah orang yang menikahkan seorang wanita dengan seorang pria (Ali, 2012:14). Syarat-syarat wali merdeka, berakal, sehat, dan dewasa, baik dia seorang muslim maupun budak. Budak, orang gila, dan anak kecil tidak dapat menjadi wali karena mereka tidak berhak mewalikan dirinya sendiri, apalagi terhadap orang lain (Sabiq, 2006:11). Ketentuan yang dianggap sah untuk menjadi wali perempuan ialah menurut susunan yang dibawah ini, karena wali-wali itu memang telah diketahui orang yang ada pada masa turun ayat: "Janganlah kamu keberatan menikahkan mereka." (Q.S 02: 232).

Begitu juga hadis Ummi Salamah yang telah berkata kepada Rasulullah saw: "Wali saya tidak ada seorangpun yang dekat."

Semua itu menjadi tanda bahwa wali-wali itu telah diketahui (dikenal).

Menurut Sabiq, (2006:11) susunan wali ialah, bapaknya, kakeknya, saudara laki-laki yang seibu-sebapak, saudara laki-laki yang sebapak, anak laki-laki dari saudara laki-laki yang seibuk sebapak, anak laki-laki dari saudara laki-laki yang sebapak, saudara bapak yang laki-laki, anak laki-laki dari pamanya yang dari pihak bapaknya, dan wali yang terakhir wali hakim.

\section{METODE}

Metode penelitian yang digunakan adalah metode lapangan (fieled research), yang mana penelitian ini menitik beratkan pada hasil pengumpulan data dari informan yang telah ditentukan. Sedangkan teknik pengumpulan data yang digunakan adalah wawancara, observasi dan dokumentasi. Sumber data yang digunakan adalah sumber data primer dan sekunder. Keabsahan validitas data mengggunakan triangulasi teknik dan triangulasi sumber, sedangkan analisis data menggunakan reduksi data, penyajian data, conlusion verivicatio.

\section{HASIL PENELITIAN DAN PEMBAHASAN}

Kekerasan adalah kata yang biasa diterjemahkan dari kata violence, yang dalam bahasa latin biasa disebut violentia. Violence erat berkaitan dengan gabungan kata latin "vis" (daya atau kekuatan) dan latus yang berasal dari kata ferre (membawa) yang kemudian berarti membawa kekuatan (Galtung, 1992:62). 
Makna kekerasan dalam bahasa Inggris yakni violence diartikan sebagai suatu serangan atau invasi (assault) terhdap fisik maupun integrasi mental psikologis seseorang (Barkatullah dan Prasetyo, 2006:279).

Sedangkan menurut Mufidah kekerasan merupakan suatu tindakan yang dilakukan oleh seseorang atau sejumlah orang yang berposisi kuat (merasa kuat) kepada seorang atau sejumlah yang berposisi lemah (dipandang lemah atau dilemahkan), yang dengan sarana kekuatannya, baik secara fisik atau non fisik dapat dikategorikan sebagai pelanggran hak-hak asasi manusia (Wahid dan Irfan, 2011:30).

Menurut WHO, kekerasan adalah penggunaan kekuatan fisik dan kekuasaan, ancaman atau tindakan terhadap diri sendiri perorangan, atau sekelompok orang atau masyarakat yang mengakibatkan atau kemungkinan besar mengakibatkan memar, trauma dan perampasan hak (Pemprop DKI, 2004:21).

Jadi, terminologi kekerasan mempunyai ciri bahwa tindakan tersebut dapat berupa fisik maupun non fisik (psikis), dapat dilakukan secara aktif mapun dengan cara pasif (tidak berbuat), dikehendaki atau diminati oleh pelaku, ada akibat atau kemungkinan akibat yang merugikan korban (fisik atau psikis) yang tidak dikehendaki oleh korban (Soeroso, 2010:60).

Berbagai pendapat, persepsi, dan definisi mengenai kekerasan dalam rumah tangga berkembang dalam masyarakat. Pada umumnya orang berpendapat bahwa kekerasan dalam rumah tangga adalah urusan intern keluarga dan rumah tangga. Anggapan ini telah membudaya bertahun, berabad bahkan bermilenium lamanya, di kalangan masyarakat termasuk aparat penegak hukum. Jika seseorang (perempuan atau anak) disenggol di jalanan umum dan ia minta tolong, maka masyarakat termasuk aparat polisi akan segera menolong dia. Namun jika seseorang (perempuan dan anak) dipukuli sampai babak belur di dalam rumahnya, walau pun ia sudah berteriak minta tolong, orang segan menolong karena tidak mau mencampuri urusan rumah tangga orang lain.

Kekerasan dalam rumah tangga juga diistilahkan sebagai kekerasan domestik yaitu kekerasan yang terjadi di dalam rumah tangga, dimana pelaku dan korbannya memiliki hubungan khusus atau pelaku dan korban tinggal dalam satu atap. Menurut Gosita (2004:269), bahwa kekerasan dalam rumah tangga adalah "berbagai macam tindakan yang menimbulkan penderitaan mental, fisik dan sosial pada para anggota keluarga oleh sesama anggota keluarga (anak, menantu, ibu, ayah, istri, suami)".

Berdasarkan pendapat dari Arif Gosita, dapat ditarik kesimpulan bahwa kekerasan dalam rumah tangga bisa menimpa siapa saja termasuk ibu, bapak, suami, istri, anak atau pembantu rumah tangga. Namun secara umum pengertian kekerasan dalam rumah tangga lebih dipersempit artinya sebagai penganiayaan oleh suami terhadap istri. Hal ini bisa dimengerti karena kebanyakan korban kekerasan dalam rumah tangga adalah istri. Sudah barang tentu pelakunya adalah suami "tercinta". Meskipun demikian 
tidak menutup kemungkinan "suami" dapat pula sebagai korban kekerasan dalam rumah tangga oleh istrinya.

Sedangkan kekerasan dalam rumah tangga menurut undang-undang No 23 pasal 1 ayat (1) tahun 2004 tentang Penghapusan Kekerasan Dalam Rumah tangga dinyatakan bahwa:

Kekerasan dalam rumah tangga adalah setiap perbuatan terhadap seserorang terutama perempuan, yang berakibat timbulnya kesengsaraan atau penderitaan secara fisik, seksual, psikologis, dan/atau penelantaran rumah tangga termasuk ancaman untuk melakukan perbuatan, pemaksaan, atau perempasan kemerdekaan secara melawan hukum dalam lingkup rumah tangga (Anonimous, 2007:248).

Pasal diatas menyebutkan bahwa kasus kekerasan dalam rumah tangga adalah segala jenis kekerasan (baik fisik maupun psikis) yang dilakukan oleh anggota keluarga kepada anggota keluarga yang lain (yang dapat dilakukan oleh suami kepada istri dan anaknya, atau oleh ibu kepada anaknya, atau bahkan sebaliknya). Dari uraian di atas tentang pengertian kekerasan dalam rumah tangga, dapat disimpulkan bahwa, yang dimaksud dengan kekerasan dalam rumah tangga adalah segala bentuk kekerasan, baik kekerasan fisik, psikis, ekonomi dll, yang terjadi di dalam rumah tangga. Jadi ketika kekerasan tersebut tidak terjadi di dalam satu atap dimana korban dan pelakunya mempunyai "hubungan sedemikian rupa" maka hal tersebut bukanlah kekerasan dalam rumah tangga, dan tidak bisa dituntut dengan undang-undang No. 23 Tahun 2004 tentang Pemberantasan Kekerasan dalam Rumah Tangga.

Mendengar kata kata "kekerasan dalam rumah tangga" kebanyakan orang langsung berspekulasi atau berfikiran bahwa sudah pasti dilakukan penyerangan, pemukulan atau sebagainya karena kebanyakan orang berfikiran bahwa kekerasan pasti hanya berupa siksaan fisik.

Kekerasan dalam rumah tangga pada dasarnya dapat dibagi menjadi empat bentuk yaitu: kekerasan fisik, psikologi, seksual, dan penelantaran terhadap keluarga. Ketiga jenis kekerasa itu mungkin sering dijumpai disekitar kita tapi mungkin kebanyakan orang kurang menyadari bahwa seseorang yang ditekan secara psikologis, seksual dan ditelantarkan di keluarga termasuk kedalam kategori kekerasan dalam rumah tangga.

Undang-undang No. 23 Tahun 2004 tentang Penghapusan Kekerasan Dalam Rumah Tangga, kekerasan dibagi menjadi empat (4) jenis, yaitu:

1) Kekerasan Fisik

Berdasarkan Pasal 6 undang-undang No. 23 Tahun 2004, kekerasan fisik dapat diartikan sebagai segala Perbuatan yang mengakibatkan rasa sakit, jatuh sakit, atau luka berat. Kekerasan tersebut dapat berupa menendang, memukul, dan lain sebagainya yang berhubungan dengan menyakiti atau melukai fisik korban.

2) Kekerasan Psikis

Pasal 7 undang-undang No. 23 Tahun 2004, kekerasan psikis adalah segala Perbuatan yang mengakibatkan ketakutan, hilangnya rasa percaya 
diri, hilangnya kemampuan untuk bertindak, rasa tidak berdaya, dan atau penderitaan psikis berat pada seseorang. Kekerasan psikis tersebut di atas, dapat berupa menanamkan intimidasi untuk menimbulkan rasa takut, menghina, memaki, merendahkan harga diri, menyekap, dan sebagainya. Pada kekerasan Psikologis, dampak yang dirasakan sebenarnya jauh lebih menyakitkan dibanding kekerasan fisik, selain itu, bentuk tindakan ini sulit untuk diidentifikasi karena bergantung pada keadaan jiwa seseorang. Oleh karena itu, untuk mengidentifikasi akibat yang ditimbulkan oleh kekerasan psikis tersebut sangat sulit untuk di ukur.

3) Kekerasan Seksual

Pasal 8 undang-undang No. 23 Tahun 2004 dikatakan bahwa Pemaksaan hubungan seksual yang dilakukan terhadap orang yang menetap dalam lingkungan rumah tangga atau terhadap seseorang dalam lingkup rumah tangganya dengan orang lain untuk tujuan komersial dan atau tujuan tertentu. Kekerasan seksual adalah setiap penyerangan yang bersifat seksual terhadap perempuan, baik setelah terjadi persetubuhan atau sebelum.

Bentuk-bentuk kekerasan ini dapat berupa pemaksaan hubungan seks tanpa persetujuan, mendesakkan hubungan seks dengan melakukan penganiayaan, mengisolasi atau menjauhkan istri dari kebutuhan batin sang istri.

4) Penelantaran Rumah Tangga

Menurut Pasal 9 ayat (1) undang-undang Penghapusan Kekerasan dalam Rumah Tangga bahwa; Setiap orang dilarang menelantarkan orang dalam Iingkup rumah tangganya, padahal menurut hukum yang berlaku baginya atau karena persetujuan atau perjanjian ia wajib memberikan kehidupan, perawatan, atau pemeliharaan kepada orang tersebut.

Selanjutnya dalam Pasal 9 ayat (2) bahwa; Penelantaran juga berlaku bagi setiap orang yang mengakibatkan ketergantungan ekonomi dengan cara membatasi dan atau melarang untuk bekerja yang layak di dalam atau di luar rumah sehingga korban berada di bawah kendali orang tersebut.

Undang-undang Penghapusan Kekerasan dalam Rumah Tangga yang disahkan tahun 2004 merupakan hasil perjuangan panjang kelompok perempuan di Indonesia. Undang-undang Penghapusan Kekerasan dalam Rumah Tangga berangkat dengan tujuan untuk melindungi perempuan khususnya dari kekerasan dalam rumah tangga. Tujuan ini sebenarnya masih dapat kita lihat dalam Ketentuan Umum undang-undang Penghapusan Kekerasan dalam Rumah Tangga (Liniawati, t.t:153154). Dalam penjelasan undang-undang No. 23 tahun 2004 tentang Penghapusan Kekerasan dalam Rumah Tangga disebutkan bahwa pembaharuan hukum yang berpihak pada kelompok rentan atau subordinasi, khususnya perempuan, menjadi sangat diperlukan sehubungan dengan banyaknya kasus kekerasan, khususnya dalam rumah tangga (Soeroso, 2010:89). 
Lahirnya undang-undang Penghapusan Kekerasan dalam Rumah tangga merupakan salah satu tonggak sejarah bagi upaya perlindungan terhadap korban kekerasan yang terjadi dalam lingkup rumah tangga khususnya kaum perempuan dan anak sebagai kelompok yang rentan menjadi korban kekerasan. Di samping itu undang-undang ini juga mengatur tentang langkah-langkah antisipasi lahirnya kekerasan baru serta adanya kejelasan sanksi yang tegas bagi pelaku kekerasan (Ridwan, 2006:80).

Pembaharuan hukum diperlukan karena undang-undang yang ada belum memadai dan tidak sesuai lagi dengan perkembangan hukum masyarakat. Sehubungan dengan itu, didorong karena adanya suatu kebutuhan karena maraknya tindak kekerasan oleh suami, terhadap anggota keluarganya, yang terjadi dalam rumah tangga. Walaupun secara umum di dalam Kitab Undang-undang Hukum Pidana (KUHP) telah diatur mengenai penganiayaan dan kesusilaan serta penelantaran orang yang perlu diberi nafkah dan kehidupan. Namun, tidak sepenuhnya dapat menangani kasus-kasus yang terjadi dalam rumah tangga. Oleh karena itu, dibutuhkan undang-undang khusus (Lex Speciallis) (Mualifin, 2003:5). Kasus tersebut "hanya" digolongkan pada perbuatan pidana biasa, bukan merupakan delik khusus yaitu kekerasan dalam rumah tangga (Soeroso, 2010:89).

Sebelum adanya undang-undang No. 23 tahun 2004 seakan-akan tidak pernah terjadi kekerasan dalam ruang lingkup rumah tangga. Karena dahulu penanganan kekerasan dalam rumah tangga selalu terlambat. Artinya, korban atau keluarganya baru melaporkan kekerasan yang terjadi setelah mengalami luka parah atau bahkan telah meninggal dunia. Perbuatan pidana tersebut biasanya dituntut berdasarkan pasal 351 KUHP tentang penganiayaan atau penganiayaan yang menyebabkan matinya korban (pasal 351 ayat (3) KUHP). Kasus tersebut hanya digolongkan pada perbuatan pidana biasa, bukan merupakan delik khusus yaitu kekerasan dalam rumah tangga (Soeroso, 2010:36).

Dalam hal penganiayaan terhadap istri (domestic violence) undangundang Penghapusan Kekerasan dalam Rumah Tangga memeberikan pemberatan hukuman, namun KUHP tidak mengaturnya dalam bab atau pasal tersendiri. Selain itu, KUHP hanya mengakui kekerasan fisik sebagai bentuk kejahatan, tidak memepertimbangkan kekerasan psikis atau seksual (Soeroso, 2010:6).

Undang-undang Penghapusan Kekerasan dalam Rumah Tangga selain mengatur ikhwal pencegahan dan perlindungan serta pemulihan terhadap korban kekerasan dalam rumah tangga, juga mengatur secara spesifik kekerasan yang terjadi dalam rumah tangga dengan unsur tindak pidana yang berbeda dengan tindak pidana penganiayaan yang diatur dalam KUHP ( Soeroso, 2010:90 ).

Jadi, keberadaan undang-undang No.23 tahun 2004 tentang Penghapusan Kekerasan dalam Rumah Tangga memiliki konstribusi positif dalam penegakan hukum kekerasan dalam rumah tangga di Indonesia. 
Dengan adanya Undang-undang ini polisi dapat melindungi korban sekaligus ada kepastian hukum bagi korban dalam mencari keadilan. Jika kekerasan dalam rumah tangga tadinya diposisikan sebagai kasus perdata yang menjadi urusan privat masing-masing individu, tetapi sekarang telah menjadi kasus pidana sehingga menjadi urusan publik.

Dari seluruh uraian dan pembahasan serta analisis yang terdapat dalam skripsi ini, maka sebagai akhir dari kajian ini akan disimpulkan halhal yang penting sebagai berikut:

1. Dari realitas sosial khususnya pada sebagian masyarakat Desa Cibeureum Kabupaten Ciamis pernikahan paksa dilaksanakan secara sirri dan dibawah umur.Pernikahan yang dilakukan secara sirri dilakukan dihadapan tokoh masyarakat yang cukup disegani di Desa Cibereum Kabupten Ciamis.

2. Penyebab pernikahan secara paksa di Desa Cibereum Kabupaten Ciamis ialah untuk mengurangi beban orang tua semata, agar orang tua terbebas dari tanggung jawab secara materi maupun yang lainnya.

3. Kekerasan yang ditemukan di lapangan adalah lebih kepada kekerasan terhadap psikis anak, seperti kasus orang tua yang memaksakan kehendaknya tanpa memerdulikan keinginan anaknya itu sendiri. Seperti yang dijelaskan diatas bahwa kekerasan psikis adalah perbuatan yang mengakibatkan ketakutan, hilangnya rasa percaya diri, hilangnya kemampuan untuk bertindak, rasa tidak berdaya, atau penderitaan psikis berat pada seseorang.

\section{KESIMPULAN}

Dari seluruh uraian dan pembahasan serta analisis yang terdapat dalam skripsi ini, maka sebagai akhir dari kajian ini akan disimpulkan halhal yang penting sebagai berikut: (1) Dari realitas sosial khususnya pada sebagian masyarakat Desa Cibeureum Kabupaten Ciamis pernikahan paksa dilaksanakan secara sirri dan dibawah umur.Pernikahan yang dilakukan secara sirri dilakukan dihadapan tokoh masyarakat yang cukup disegani di Desa Cibereum Kabupten Ciamis. (2) Penyebab pernikahan secara paksa di Desa Cibereum Kabupaten Ciamis ialah untuk mengurangi beban orang tua semata, agar orang tua terbebas dari tanggung jawab secara materi maupun yang lainnya. (3) Kekerasan yang ditemukan di lapangan adalah lebih kepada kekerasan terhadap psikis anak, seperti kasus orang tua yang memaksakan kehendaknya tanpa memerdulikan keinginan anaknya itu sendiri. Seperti yang dijelaskan diatas bahwa kekerasan psikis adalah perbuatan yang mengakibatkan ketakutan, hilangnya rasa percaya diri, hilangnya kemampuan untuk bertindak, rasa tidak berdaya, atau penderitaan psikis berat pada seseorang. 


\section{DAFTAR PUSTAKA}

Abbas, Ahmad Sudirman. (2006). Pengantar Pernikahan Analisa Antar Madzhab. Jakarta: PT Prima Haza Lestari.

Abdurrahman, (1963). Kompilasi Hukum Islam, Jakarta: Akademika Pressindo.

As'ad, Aliy, (1979). Terjemahan Fathul Mu'in Jilid 3. Yogyakarta: Menara Kudus.

Asy-Syakuni, Al Imam. (2006). Ringkasan Nailul Authar. Jakarta: Pustaka Azzam.

Ghamidi, (2010). Stop KDRT. Jakarta: Pustaka Imam Asyfi'i.HM, A Rauf. (1996 ). Munakahat dan Waris. Bekasi: Al-Furqan.

Ghazaly, Abdul Rshmsn. ( 2003 ). Fikih Munakahat. Jakarta: Kencana.

Gosita, Arief. (2004). Masalah Korban Kejahatan (Kumpulan Karangan)

Kedudukan Korban di Dalam Tindak Pidana. Jakarta: PT. Bhuwana Ilmu Populer.

Hidayatullah, Syarif. (2002). Ensiklopedia Islam Indonesia (cet ke-2). Jakarta: Jambatan.

Loppa, Baharuddin. (1996). Al-Qur'an dan Hak Asasi Manusia. Jakarta: Bhakti Prima Yasa.

Mughniyah, Muhammad Jawad. (2010). Figh Lima Madzhab. Jakarta: Penerbit Lentera.

Naruddin, Amir dan Tarigan, Azhari, Akmal. (2004). Hukum Perdata Islam di Indonesia, Studi Krtis Perkembangan Islam Dan Figh, Undang-Undang No. 1 Tahun 1974 sampai KHI. Jakarta: Kencana.

Ramulyo, Idris. (1996). Hukum Pernikahan Islam. Jakarta: Bumi Askara.

Rasyid, Sulaiman. (1992). Figh Islam ( cet ke-25 ). Bandung: Sinar Baru.

Rofiq, Ahmad. (1995). Hukum Islam di Indonesia. Jakarta: Raja Garafindo Persada.

Sabiq, Sayyid. (1992). Fiqh Sunnah (jilid 2). Beirut-Libanon: Dar al-fikr.

Soekanto, Soerjono. (2003). Penelitian Hokum Normative. Jakarta: Raja Grafindo.

Soemiyati, (1999). Hukum Pernikahan Islam dan Undang-undang Pernikahan (Undang-undang Pernikahan No. Tahun 1974 tentang Pernikahan). Yogyakarta: Liberty.

Sujarweni, Wiratna. (2014). Metodologi Penelitian. Yogyakarta: Pustaka Baru Pres. 